\title{
The Discovery of DNA: An Ironic Tale of Chance, Prejudice and Insight
}

\author{
Third Griffith Memorial Lecture
}

\author{
By M. R. POLLOCK \\ Department of Molecular Biology, University of Edinburgh \\ (Delivered at the General Meeting of the Society for General Microbiology \\ on 6 April 1970) \\ 'Truth emerges more readily from error than from confusion.' \\ FRANCIS BACON (I620), Novum Organum
}

The Council of our now almost venerable Society must, in inviting me to give the third lecture in this series, have been at their wits' end to have had to scrape the barrel so desperately.

Unlike my two illustrious predecessors who were-in very different ways-natural choices for the job, I cannot claim to have made any significant contribution to scientific knowledge in the areas where Fred Griffith did most of his work. Sincerely honoured though I am, it is obvious to me that I am not really qualified to follow in their footsteps.

So I shall not try to. And I thought that, instead of talking about recent researches of personal appeal to myself, it might be more appropriate to stand aside and view some of the historical aspects of DNA in those early days before, during and shortly after Fred Griffith recorded his all-important discovery of transformation of pneumococcal types.

Hence the rather grandiose title.

Of course I could never attempt to produce anything approaching a complete history-or even a balanced summary-of DNA in the space of one lecture. And I certainly would not wish to compete with Jim Watson's Double Helix (1) or try to touch on all the events after 1953 which comprise, in fact, most of modern molecular biology.

It is a tricky business, involving considerable personal risks, touching on contemporary history. Erwin Chargaff, very appropriately, if rather cynically, wrote (2) that such an attempt 'must be very difficult as long as some of the witnesses, with all their quirks, senilities and dubious recollections are still alive'. 'Later it will be easier,' he added, 'no one being left to protest against truth or falsehood.'

I want, if I can, to try to capture the scientific atmosphere of the years between I928, when Griffith published his now famous paper(3), through 1944 when Avery and his colleagues (4) showed that the transforming agent was DNA, to the great breakthrough in 1953 when Watson \& Crick (5) published their structure of DNA and showed how it might explain the chemical mechanism by which cells passed on their characters 
accurately to their daughter cells. And let us have no illusions about this discovery of 1953. Without doubt it represented-that is, it was the culminating point in-one of the most fundamental and important discoveries in biology of all time. This was because it shows not only how living systems replicate themselves (and not something different) but has led directly to an understanding of how their functional characters are expressed.

But, having emphasized the excitement of the concluding stages in this development of biology, it is wise to remember that the importance of the three crucial pointsGriffith's discovery of transformation (3), Avery's demonstration that the transforming material was DNA(4), and Crick \& Watson's solution(5) of its structure-rested on what Maurice Wilkins(6) has emphasized were three essential and much older basic concepts: the gene, the macromolecule and the hydrogen bond.

We could paraphrase these concepts respectively as: the 'discreteness' of the inheritance of characters, the huge size of molecules concerned with biological specificity and the great importance of weak inter-atomic bonds (as distinct from the strong covalent links of classical chemistry) in biological systems.

The theme of DNA has now permeated so deeply into the consciousness of most educated people that it is unusual still to find someone-at least in academic circleswho has never heard of it. But it still occurs. Only the other day Bill Hayes and I were showing off our laboratories to a charming and distinguished personality in the Fine Arts Department of Edinburgh University. We stopped proudly before our threedimensional atomic model of the DNA double helix. 'What is that?' our visitor queried. 'That,' we replied, 'is DNA.' His face was blank. 'You surely know about DNA?' we unwisely reproached him. 'No,' he answered, 'I've never heard of such a thing. What is it?' Now, that's not a particularly interesting story as it stands. What made it especially odd for $u s$ was that the individual concerned happened to be the perfect double of Francis Crick. The incident had a macabre, almost nightmarish quality that, for an instant, was quite alarming: time passing backwards, visions of all the great scientists denying their discoveries and pleading total ignorance of the field in which they made their names. But at least, after recovery, it reminded us that it takes a very long time for great basic discoveries-as distinct from purely technical advancesto take a real hold on ordinary people.

And we are only really at the very beginning of the sequence of repercussions that the discovery of DNA has initiated. Freud, it is said, believed that there were three really outstanding events in the evolution of human knowledge: the Copernican Theory of the Solar System; the Darwinian Theory of Evolution; and (not surprisingly) the Recognition of Unconscious Mental Processes.

Many will, of course, disagree with such a list, which by its nature must be a gross over-simplification. But the Understanding of the Chemical Basis of Life (which must, of course, include Heredity) might now be a strong candidate for inclusion as a fourth item, though this may be premature and, unlike the others, would not, I think, amount to a new scientific paradigm in the sense used by Kuhn(7). However that may be, it is interesting that all four items share the property of whittling down the cosmic significance of man. The first showed that man is just part of the Universe (not the centre), the second that man is just part of all living systems (not something fundamentally distinct), the third that man's will and personality-his 'soul'-are just parts of mental processes in general, and the fourth (the discovery of DNA) that living 
systems themselves are just parts of all chemical processes, albeit rather complicated ones and not subject to transcendent vitalistic forces.

Through these discoveries the mystic concept of the stature of man and his cosmic significance has been superseded by a complementary increase in his potential control over the Universe-or what should now be paraphrased as a 'recognition of the increasingly important part the phenomenon of man is playing in the evolution of the Universe'. At all events, he still thinks he is awfully important.

I am rather afraid that Fred Griffith might have been rather shocked, if not horrified, to know that his own work was considered a vital link in the chain of advances in knowledge which could be analysed in such materialistic terms.

But this is the way with history. And I am very conscious that in choosing to tackle this subject of DNA historically I am running many risks-not least of which is that of being a terrible bore-especially to the young.

Peter Medawar, paying tribute to the vital part played by Griffith's discovery, wrote in a review(8) of Jim Watson's Double Helix (which makes no mention of Griffith): 'A great many highly creative scientists... take it quite for granted that an interest in the history of science is a sign of failing or unawakened powers... Science in some sense comprehends its history within itself. No Fred, no Jim: that is obvious, at least to scientists, and being obvious, it is understandable that it should be left unsaid ... the history of science does not often interest the scientist as science.'

Whitehead (9) - in a rather different sense-went further when he remarked almost cynically that: 'A science that hesitates to forget its founders is lost.'

Science history need not be a bore, but my apology tonight is rather in the nature of hoping that it can interest the scientist as science; or at least in close relation to the practice of science; that attempts to follow what in fact has been taking place over the period of an important discovery-the prejudices, the mistakes, the desires and personalities of the participants, the lucky and unlucky chances, the synthesis of ideas, the symbols and analogies, the relationships between entities and the sequence of eventsmay help in understanding the way human beings behave in their search for knowledge and so give some hints as to how to try to do it better.

The early history of DNA is full of instances of irrational forces that seem both to hinder and to help. But I can really do little more than indicate how the wind was blowing. It is surely premature to try to offer any sort of general theory of discovery. The story of DNA will mean different things to different people; but I believe it carries with it a few clues of how such discoveries are made-or perhaps, rather, of what sorts of things confuse us and delay the rate of progress.

The beginning of the story-of course, there is really no true beginning-lies long before 1928. Fred Griffith never hinted in his paper(3) that he contemplated that nucleic acid might have had a part to play in his transformation. But it would have been quite logical and possible for him to have done so, and 'nucleoproteins' were in fact discussed in his laboratory(10) in relation to the phenomenon.

In fact, nucleic acids were first discovered and characterized by Miescher in I869, i.e. almost exactly Ioo years ago(11). Indeed, this remarkable chemist devoted most of his life to studying them. Moreover, as pointed out by Olby \& Posner(12), his views on the chemical basis of inheritance were remarkably far-seeing when, in I892, he postulated heredity being derived from the 'stereo-architecture of only a few very large, complicated molecules'. 
It might have been supposed that he was thinking of nucleic acids since he worked for most of his life on little else. Ironically enough, however, it seems he was probably referring to proteins because Mirsky (11) quotes him as saying in an article attacking Weismann (who was in favour of nuclein being the heredity substance) that 'his [Weismann's] speculations are unclear and derived from an outmoded kind of chemistry. When, as is quite possible, a protein molecule has 40 asymmetric $\mathrm{C}$ atoms so that there can be a billion isomers...my [stereochemical] theory is better suited than any other to account for the unimaginable diversity required by our knowledge of heredity.'

It was, indeed, at about that time that Staudinger was emphasizing a completely new idea for chemistry - the macromolecular polymer of biological origin. Even earlier than that v. Nägeli was developing the idea of an 'idioplasm'-an intracellular substance that was continuous through cell division and carried with it hereditary determinants (a sort of Weismann substance at the intercellular level), a concept which was well received by people such as de Vries and E. B. Wilson. The possibility came to be considered by several contemporary biologists that it might be identical with chromatin, the material associated with chromosomes.

'In the physiological aspect', wrote Wilson in the first edition of his famous book (13) 'inheritance is the recurrence, in successive generations, of like forms of metabolism; and this is effected through the transmission from generation to generation of a specific substance or idioplasm which we have seen reason to identify with chromatin.... In I895, in another context(14), he had stated that: ' $\ldots$. [this] seems to show that the chromosomal substance, the chromatin, is to be regarded as the physical basis of inheritance'. And he went on: 'Now, chromatin is known to be closely similar to, if not identical with, a substance known as nuclein, which analysis shows to be a tolerably definite chemical compound composed of nucleic acid and albumin. And thus we reach the remarkable conclusion that inheritance may perhaps be effected by the physical transmission of a particular chemical compound from parent to offspring.'

I have quoted these passages by Wilson at length because I think they illustrate two interesting points. The first is the remarkable extent-under the existing circumstances - to which the great biologists at the end of the last century had begun to grasp the situation: had got the right end of the stick, so to speak. The second is their failure to recognize the need to explain the basic phenomenon of inheritance: namely, the mechanism by which a character, or the chemical basis of a character, is copied, is multiplied-indefinitely-through successive generations. They talk only of 'transmission' of a character or by a substance-taking it for granted that the substance will be faithfully replicated somehow. They barely do that, because in fact I do not believe they are completely clear that something must be increased, although-and this is the point--they have arrived at the conclusion that the 'something' is a definable chemical substance. The problem-as it was seen much later on, in the present century-was not then being defined. Nor was it, as I shall emphasize later on, apparently appreciated by Griffith. The 'self-reproducing' molecule was not an idea that appeared until much later. At the best, heredity was, in ancient days, the passing on of a minute replica of the parent to the progeny: the homunculus in the head of the sperm, etc. Self-reproduction must have been regarded vitalistically, as an essential and natural property of 'life' and 'living systems'-not properly recognized as a phenomenon needing an 
explanation, barely recognized as a phenomenon at all-as universal gravity before Newton, or the relativity of motion before Einstein.

It was regarded as being as natural and inherent a feature of 'life', as falling bodies were regarded by the Aristotelians as 'naturally' seeking their true home (the Earth) or the heavenly spheres were regarded by Copernicus and Galileo as moving naturally in circles, or by Descartes and Newton naturally in straight lines by their own inertia.

This problem of recognizing a problem may, of course, depend upon there being the tools for beginning to solve it. But, above all, it makes one wonder what sorts of problem we may not be capable of recognizing at the moment. Biologists no doubt would like to think they were all a matter for physicists!

With the turn of the century, nucleic acids began to suffer a decline in prestige which persisted until the mid I930s. For a long time their possible biological significance seems to have been almost completely rejected or forgotten. Even E. B. Wilson(15) in the second edition of his book, published in I900, seems to have begun to lose the original excited interest he showed in his first edition written only five years previously. He already comes out clearly against the 'genetic continuity of chromosomes depending upon a persistence of chromatin'.

In 1909 Strasburger explained the diminishing interest in 'nuclein' when he reasoned that "chromatin cannot itself be the hereditary substance [because] the amount of it is subject to considerable variation in the nucleus according to its stage of development' (11). (This argument was still operative in the I940s.)

And in the third edition (1925) Wilson now writes(16): 'It is an interesting fact, which has been emphasized by biochemists, that apart from the characteristic differences between animals and plants referred to above [he means RNA for plants and DNA for animals - the dogma then current], the nucleic acids of the nucleus are on the whole remarkably uniform, showing with present methods of analysis no differences in any degree commensurate with those from the various species of cells from which they are derived. In this respect they show a remarkable contrast to the proteins which, whether simple or compound, seem to be of inexhaustible variety. It has been suggested, accordingly, that the differences between different "chromatins depend upon their basic or protein components and not upon their nucleic acids".'

The cause of this 'eclipse period' was paradoxically, but unquestionably, the rise of biochemistry; in particular, of course, the recognition of the vast variety of proteins (definable as chemical compounds the more strikingly after the crystallization of haemoglobin and egg albumen) with their huge range of distinct biological specificities.

For the chemists who were tearing to pieces the delicate structure of the cell with ever-mounting violence, naturally flushed with the success of isolating the key and relatively robust small molecules of amino acids, vitamins and co-enzymes, the delicate macromolecular 'goo' of nucleic acid may have seemed an amorphous mixture of irrelevancies. It is surprising that the integrity and native configuration of at least some proteins seem to have survived their attack. Nucleic acids were still isolated, but grossly degraded in what was believed to be a tetranucleotide state-containing an emasculated sequence of only four bases.

Even as late as the I920s arguments were occurring as to whether nucleic acids might possibly range up to a size as could include five or even six bases. And it was not until the I930s that the older, gentler methods for their extraction began to be reinstated 
and it was slowly realized that their molecular weights might be very much larger than the 1500 daltons appropriate for a single tetranucleotide. Even then, most nucleic acid chemists, such as Levene \& Bass (whose large book(17) on their properties barely touches on their possible biological significance), regarded them as homopolymers of balanced tetranucleotides containing all four bases in the same order and proportions.

A lot of the trouble, of course, was poor techniques - both for estimating nucleotides and separating what were the grossly degraded hydrolytic products of macromolecular nucleic acids from each other.

It was also misleading that the proportions of bases in the only types of DNA then being studied-those from higher animals-'happened', so to speak, to be roughly equal. We would say now that their proportions of guanine and cytosine $(G+C)$ of total base present being not far off $50 \%$, and since content of guanine must equal that of cytosine, and adenine content must equal that of thymine in all double-stranded DNA, all four bases would inevitably be present in roughly equal amounts. Had the chemists of those days systematically studied bacterial DNA where $\mathbf{G}+\mathbf{C}$ content can vary between $25 \%$ and $75 \%$, the tetranucleotide hypothesis might have died an earlier death.

It is interesting and somewhat ironical to note that in 1931 Levene \& Bass(17) do in fact mention the nucleic acid of tubercle bacilli, with a $\mathrm{G}+\mathrm{C}$ content of DNA now known to be around $66 \%$ (Hill(18)), as yielding a material which showed great difficulty in giving a constant composition. But this anxiety was concentrated on the finding that the material contained both thymine and uracil. That was either against the great current dogma or showed that bacteria were neither plants nor animals!

The dogma in those days, it will be remembered, was that the nucleic acid of plants ('yeast nucleic acid') was always RNA and that of animals ('thymonucleic acid') DNA. And this further confused the picture.

By then, however, things were perhaps just beginning to look up. The chemical nadir for nucleic acids must surely be represented by some of the opinions expressed in a well-known 'monograph' on Nucleic Acids(19) published in 1914, with a preface beginning 'The Nucleic Acids constitute what is possibly the best understood field of physiological chemistry', at the time of the most rapid advances in the Hopkins School of Biochemistry! Its contents include sections such as: 'Both nucleic acids [thymus and yeast] also yield cytosine... but where animal nucleic acids yield thymine, plant nucleic acids yield uracil and this distinction holds in every case. Finally, plant nucleic acids contain a pentose group... On the contrary, all animal nucleic acids give rise to laevulinic acid which is formed from a hexose group in their molecule. These statements are universally granted, and one sufficiently alert to the possible sources of experimental error cannot obtain results which differ from them.' And a little later on: '...It is therefore necessary to discuss only two nucleic acids in order to have an understanding of them all.' It is possible to understand and forgive ignorance and mistakes; but surely not such complacent arrogance as that?

It seems to have been almost in the very nature of biochemistry in its early daysperhaps its need to 'prove itself' as respectable chemistry applied to biological tissuesto operate against ultra-dangerous concepts such as those of huge molecules, weak inter-atomic forces and a type of inter-molecular specificity that might appear ludicrous to the orthodox chemist and mechanistic to biologists.

Even Gowland Hopkins, who pulled no punches in his support for the analytic 
attack chemists were making on biological systems at that time, was very much on the defensive when he pointed out in a lecture at Harvard in $1936(20)$ that 'so long as [the modern biochemist's] analysis involves the isolation of events, and not merely of substances, he is not in danger of so departing from reality that his studies have no longer biological meaning'. Thinking of the structure of DNA and how its solution only 17 years later provided the clue to an understanding of heredity and the biosynthesis of proteins, one is struck by how wide of the mark this observation proved to be. Hopkins, indeed, considered chemical structure could form the basis for explaining morphology, but no more. And two years later he was hard put to it confronting the Cambridge school of cytology under James Gray in defending even that possibility (21).

At the same time, many of the earlier biochemists, like some of the younger and lesser molecular biologists of the present day in their turn, were brash in their claims and interpretations. They tended to shorten and oversimplify the gap between the function and structure of biological systems (on the one hand) and the chemistry of the molecules of which such systems are composed (on the other). As so often happens, the rise of one science set back the development of another.

This, then, was the climate into which Fred Griffith's famous transformation paper was born in I928(3). And he entered the field laterally, so to speak, without, I believe, realizing it and without appreciating much of what we now, with hindsight, know to have been vitally relevant to the whole history of DNA.

Fred Griffith was a modest and retiring personality who enjoyed working quietly on his own, shunning scientific meetings. According to his colleague V. D. Allison(10), he had to be practically forced into a taxi to attend the London International Microbiology Congress in 1936. And then, I am told(22), he reluctantly and nervously read out his rather boring paper in such an unenthusiastic manner that those not closely concerned with the detailed streptococcal typing techniques he was expounding must hardly have felt it was worth listening to. This was, it seems, the only paper he ever delivered at an open meeting and it had, of course, nothing to do with transformation.

He would not even be persuaded to give an informal paper to the Medical Research Club with a view to becoming a member(22).

He was also very reluctant to write papers; but immensely hard-working, meticulously careful and scrupulously honest in his researches. Before 1928 he had made important contributions to the epidemiology of infectious diseases, first with his brother Stanley in typing tubercle bacilli and later, more or less on his own, in the classification of streptococcal types as well as Salmonella and staphylococci. At that time, Graham Wilson has pointed out (23), he was firmly convinced of the fixity of bacterial types-at least in so far as the mammalian tubercle bacilli were concerned. The vagaries of the pneumococcus in the changes from smooth, virulent (S) to rough, attentuated (R) and back again may well have been a source of irritation as well as interest. His description (3) of his great discovery occupied quite a small proportion of what would nowadays be regarded as an immensely long 46-page paper on "The significance of pneumococcal types'. In this he showed that heat-killed S pneumococci of (for instance) type I could, when inoculated into mice along with living $\mathrm{R}$ cells originally of type II, lead to the appearance of virulent $S$ cells of type I (and vice versa). It must surely have been made almost despite his own emotional inclinations, rather than, as is so often the case, because of them. 
We are used to hearing about how Copernicus, the mystic Sun-worshipper, must have been irrationally impelled towards a theory of the Universe that made the Sun, rather than the Earth, its centre. And, again, about how Pasteur himself, a devout Christian of the old school, launched himself so fiercely into the controversy against the then quite fashionable doctrine of Spontaneous Generation because the idea of the creation of life without God was an impious thought.

With Fred Griffith, it must, if anything, have been quite the opposite. It was his great care, perfectly planned controls and scrupulous honesty that forced him not to hedge and towards the correct conclusion that (to quote) 'there seems to be no alternative to the hypothesis of transformation of type'(3). One almost wonders to what extent he might have wished for an alternative! And he adds that 'this is considered less unacceptable than previously because it is now (since the last few years) widely recognized that $\mathrm{R}$ forms occur spontaneously and can spontaneously revert to their own $\mathrm{S}$ type'. In fact, ironically enough, the $\mathrm{S}$ to $\mathrm{R}$ change (in the presence of immune serum) was well appreciated even in the previous century, and we now know that it and the reversion of $\mathrm{R}$ to $\mathrm{S}$ must (presumably) be due usually to point mutations--quite a different process from transformation, which involves substitution of one or more genes (i.e. a long stretch of DNA), through DNA recombination, by their allelic homologues.

The demonstration of specific transformation was an achievement in other respects, as perhaps would only be properly realized if it is appreciated how confusing the situation must have appeared at the time, due to facts such as the following:

(I) Not only could R types revert to their 'own' $S$ types spontaneously, but it had long been known that this reversion could be greatly enhanced by a number of nonspecific factors, including the addition of heat-killed pneumococci of the same or another type. (This was currently thought to be due to the action, in the culture, of toxic 'aggressins' which operated against leucocytes.)

(2) The temperatures used for killing the $\mathrm{S}$ types of cell affected the transforming abilities of different types differentially. Quite apart from that, transforming abilities differed between types, as also did non-specific stimulation of reversions.

However, the key fact elucidated by Griffith was that if change of type occurred, it was only in the presence of heat-killed cells of another type and towards the same type as that of the added, killed cells.

I hope it will not be taken in any way depreciatory of his achievement if I point out that Griffith seemed to have had little idea of how this transformation came about, nor even of its great and ultimate significance. His discovery was a classic instance of pure serendipity.

After all, he was, in essence, a naturalist. His interpretation was teleogical and looked at from the point of view of the pneumococcus which, being the kind of organism with which he was associated for most of his working life, I suspect he must have loved, with the quiet, but usually unexpressed, passion that all true biologists have for the system with which they work.

'The apparent transformation,' he writes, 'is not an abrupt change of one type into another, but a process of evolution through an intermediate stage, the R form, from which the type characters have been obliterated.' In this, of course, he is quite wrong, although, for purely technical reasons, it was a long time before it was found possible to transform $\mathrm{S}$ types directly into one another. This view is also rather inconsistent with 
the attitude he takes elsewhere in the same paper postulating the idea of 'cycles of states' through which the pneumococcus may pass, and the feeling that, perhaps, in the $\mathrm{R}$ state remnants of the previous $\mathrm{S}$ state had not been entirely eliminated: 'minor' components of all types could have been present in all types after all, he points out.

'It would appear', he says, 'that the type I antigen no longer serves its purpose [my italics] in the presence of the immune substance formed during convalescence, and the pneumococcus consequently develops its type II side... The idea of a regular sequence of changes in the type of pneumococcus before the development of pneumonia and during recovery... is in harmony with the experimental data.'

Although apparently quite clear that the controlling factor in manifestation of type specificity was the substance responsible for forming the 'specific soluble substance' (SSS) (i.e. the polysaccharide of the capsule) and not the SSS itself, he did not distinguish clearly between it and the factor actually responsible for transformation which, very understandably, he took for granted must be a protein. The actual words he used were: 'When the $\mathrm{R}$ form of either type is furnished under suitable experimental conditions with a mass of the $S$ form of the other type, it appears to utilize that antigen as a pabulum from which to build up a similar antigen and thus to develop into an $\mathrm{S}$ strain of that type.' This seems somewhat inconsistent with his clear conclusion that the heat-lability of the transforming factor indicated that it could not be the heat-stable polysaccharide antigen itself.

Apart from that, and, as with the biologists of the last century to whom I have already referred, there does not appear to be any realization that there is a fundamental problem here. 'Pabulum' simply means a source of food, and there is no indication that what had to be explained was how such a specific pabulum (be it antigen itself or antigen-forming factor) gave rise-indefinitely - to more of the same pabulum. In fact, scientists were only just beginning seriously to attempt to do this at the time, nor indeed was the problem-clear and obvious though it seems to us now-really formulated properly for another eight years, when J. B. S. Haldane wrote a remarkable article to which I will refer in detail later on.

However, H. J. Muller, in a brilliant essay (24) written as early as 1922, had pointed to the difficulty of understanding the 'self-propagation' property of the gene: '... the fact that, within the complicated environment of the cell protoplasm, it reacts in such a way as to convert some of the common surrounding material into an end-product identical in kind with the original gene itself'. But he later (in the same article) admits that 'there is yet no means of deciding whether the chief features of the autocatalytic mechanism [of the gene] reside in the structure of the genes themselves, and that the outer protoplasm does little more than provide the building material...', or whether 'gene structure might mean nothing more than the possession by each gene of some very simple character... which enables each gene to enter into combination with certain highly organized materials in the outer protoplasm in such a way as to result in the formulation "by" the protoplasm of more material like this gene which is in combination with it'.

We should now, of course, describe the problem of deciding between these two alternatives as that of determining where the exclusive information for gene replication resides: in the DNA itself or in molecules used for the biosynthesis of DNA, namely the enzymes and building blocks concerned.

Fred Griffith's paper was not ignored (as might almost have been expected). His 
findings were confirmed by Neufeld \& Levinthal(25) and others only a year or two later. But there was considerable scepticism and even frank disbelief amongst many bacteriologists, none of whom, however, as Graham Wilson emphasized(23), would 'dare express their doubts in public' because of his great reputation for scientific integrity. 'Griffith,' Wilson says, 'they thought might have been misled by some technical error, but he would never have put his name to anything in whose truth he was not profoundly convinced.'

In fact, his firm conclusion on the reality of type transformation must have been all the more convincing to others-and therefore more effective in stimulating their interest-just because he was so well known as a sceptic and as one who demanded the most rigorous proof of a new discovery before accepting it. According to his assistant, W. R. Maxted(26), who knew him well during the last few years of his life, he was only just beginning to accept the Lancefield group classification of streptococci in 1940, several years after it had been generally acknowledged in bacteriological circles.

He never pursued the phenomenon of transformation further himself. S. D. Elliott(22) remembers him explaining that it was now 'up to the chemists'. Nor did he, but rarely, refer to it in conversations with others. Indeed, he turned his own attention increasingly to the new problem of typing haemolytic streptococci-a matter of great importance in epidemiology - and left others to continue the task of pneumococcal typing, using the sera that he had himself prepared.

I do not believe he really could have been very much interested in the phenomenon of transformation which he himself had discovered. But he certainly had started something, and the research developments thus initiated continued-albeit slowly-in a pretty well unbroken series continuously on towards the present time.

So, after 1928, the centre of interest and activity passed to the Rockefeller Institute in New York, under the stimulating guidance of Oswald Avery.

After again confirming type transformation in vivo in 1930, Dawson(27) together with Sia(28) demonstrated the phenomenon in vitro in I93I, and Alloway's(29) successful transformation with crude cell-free extracts in 1932 and more purified preparations in $1933(30)$ strengthened the interest and importance that was beginning to be attached to it.

I do not think there is much doubt that Avery had a fair idea of what he was after and certainly of the fundamental importance of transformation. He never actually visited Griffith's laboratory in Endell Street, nor did he and Griffith ever correspond. But, according to one who knew them both well (22), they held each other in high esteem and there is no doubt that Avery was greatly stimulated by Griffith's discovery. He shared his preoccupation with pneumococci and streptococci and in some ways was a rather similar character. Both men were born within a few months of each other and were confirmed bachelors. Both were exceedingly modest, meticulously careful in their experimental work and extremely generous with the time they spent in helping others. Both were almost obsessively cautious in reaching conclusions. Avery is quoted (31) as remarking to his brother Roy, in 1943, that 'it is lots of fun to blow bubbles but it is wiser to prick them yourself before someone else tries to'. And both made their major contributions to knowledge relatively late in life. Griffith was over 50 when he discovered transformation, and Avery 67 when he published his paper on DNA as the transforming agent. Perhaps that will be an encouragement to those of us in our sixth decade, or beyond, to hope that even now all is not quite lost! 
In other respects, however, they were rather different: Avery being much more openly friendly and communicative whereas Fred Griffith was very shy and aloof and difficult to get to know.

There were others, besides Avery's group, who had been excited by Fred Griffith's discovery. In 1936 Berry \& Dedrick (32) claimed to have transformed the virus of Shope's rabbit fibroma into that of the closely related infectious myxomatosis by the addition of heat-inactivated myxomatosis virus. This effect was confirmed by others and served to strengthen Avery's interest in the whole field.

It is, however, ironic now to know that this virus 'transformation', which at the time emphasized the general significance of the pneumococcal transformation, is no longer considered to be a genetic effect at all, but according to Fenner(33), a rather complex and purely phenotypic ' rescue' of the inactivated myxoma virus due to the induction of a de-coating enzyme in the host cell which liberates, and so reactivates, the myxoma DNA.

DNA itself was still very much in the background in those days. Berry is quoted as believing that 'nucleoprotein' was the operative transforming principle in his effect. And Avery has been mentioned as 'wistfully suggesting' to Hotchkiss (34), as early as 1936, that the transforming agent 'might be a nucleic acid'. But proteins still completely dominated the field of biological specificity; and even if nucleic acids were recognized as respectable chemical entities (still, of course, largely as tetranucleotides!), they were closely linked for biologists with proteins in the 'nucleo-proteins' often referred to and well known as the major constituent of viruses which were then first being studied intensively by biochemists such as the Piries and Barbara Holmes. For instance, as late as 1938 Hopkins (21) could write: 'My colleague, Mr N. W. Pirie, has shown that the active unit in each case [of plant viruses] is, in essential, a complex protein molecule', even though I believe that Bill Pirie(35) was not himself rushing to such a conclusion and already suspected that the RNA was playing a more vital role.

Avery himself, however, may have had good reason not to be so affected by the prevailing fashion regarding the exclusive role of proteins in biological specificity. For he had been chiefly responsible(36) for demonstrating the very high biological specificity shown by the polysaccharides of the pneumococcus capsule. It could have been easier for him, than for many others, to avoid the strong prejudice against considering molecules other than proteins-nucleic acids themselves, for instance, known for half a century or more to be present in, or at least associated with, chromosomes and the nucleus-as possible repositories of powerful specificity.

But despite the remarks quoted above, even Avery seems to have been somewhat surprised at his own finding, because in a guarded letter to his brother Roy in 1943(31), previously referred to, at the time of his great discovery he writes of his conclusion that the transforming agent 'is in all probability DNA: who could have guessed it?'

In fact, however, the possible significance of nucleic acids was beginning to be appreciated by others, and Mirsky(37) had written an important review in 1943 on 'Chromosomes and nucleoproteins' in which he pointed out that 'the specificity of a nucleoprotein may reside in its nucleic acid as well as in its protein moiety'. And, discussing the chemistry of heredity, he also made the important point that "the kind of experiment that is needed to place the chemistry of the gene on a firm basis is one in which substances extracted from the chromosomes of an organism are administered to a mutant form of the same organism which suffers from a deficiency in its germinal material'. This is a pretty shrewd observation for those days and was, of course, 
exactly what Avery was doing at that very time, though neither he nor Mirsky could possibly then have analysed it precisely in that way.

Moreover, during this period, too, there were parallel relevant general advances in biology that served to prepare the way for the final breakthrough.

Caspersson and his school(38) had been developing techniques of ultraviolet spectroscopy applied to intact cells with which it was possible to demonstrate the intense absorption of wavelengths around $260 \mathrm{~nm}$. (characteristic of nucleic acidsand, of course, the single nucleotides and bases of which they were composed) within the nucleus of living cells and by this means demonstrate a rise and fall of nuclear nucleic acid in phase with the mitotic cycle.

During this period, too, the chemists and physicists were at last beginning to realize that molecules of nucleic acid were much larger than the $I 500$ daltons appropriate for a single tetranucleotide, though they still tended to be regarded as aggregates or simple polymers of 'balanced' tetranucleotides containing all four bases. But the idea of the statistical polytetranucleotide was gaining ground, largely due to the work of Gulland (39).

Their biological role, in so far as it was formulated at all, tended to be considered in the nature of structural support for the gene protein-or (at the best) as what was referred to by Darlington(40) as a 'midwife' molecule to assist non-specifically, in enabling the protein of the gene to replicate itself. '

The constant association of nucleic acids with 'self-propagating' systems such as chromosomes and viruses was, however, being stressed by workers such as Caspersson and Astbury, but with reproduction by a direct copying process analogous to crystallization. Astbury (41) in particular was understandably misled by the coincidental fact that the spacing ( $3.34 \AA$ ) of successive nucleotides in a polynucleotide column was almost exactly equal to the spacing of successive side-chains in a fully extended polypeptide.

When Avery(4) mentioned that his transforming DNA might have a molecular weight as large as 500,000 , this was not out of keeping with views of chemists and physicists, though we now know that such a size, being barely enough for a single gene, must have been grossly below that actually operative in his transformations, which involve many linked genes. It was difficult to remove DNA-ase completely from the system, and the chain length of the DNA must often have been shortened by enzymic hydrolysis both before and after uptake by the pneumococcus. This, alongside variability of competence factors, must have been largely responsible for the exasperating irreproducibility of the transformation reaction.

During this period and the early years after the identification of DNA as the transforming factor, the lack of consistency in transformation experiments was a continual source of frustration amongst workers on the problem. Indeed, inexplicable 'bad periods' still occur, at least with other transformation systems. 'Many were the times', Avery is quoted (31) as saying, 'when we were ready to throw the whole thing out of the window.'

Ideas prevalent 40 to 50 years previously, at a much less sophisticated level, were now beginning to revive. But times were not yet ripe for a concerted attack by biochemists on possible mechanisms for the biological replication of key molecules. The problem had still not been properly broadcast.

But it had been defined-defined brilliantly and correctly-if not quite for the first 
time, at least for the first time in a manner that made an impact in terms that could have been appreciated (even if they were not). This was done by J. B. S. Haldane in an article for Hopkins' 'festschrift' (42) published in 1937. Here, in passages which must be quoted at length, not only is the problem properly defined, but the whole field of molecular biology is outlined, emphasized and characterized-I 5 years or so before it really became properly recognized.

Two possibilities are now open. The gene is a catalyst making a particular antigen [referring to blood groups. M.R.P], or the antigen is simply the gene or part of it let loose from its connection with the chromosome. For one essential property of the gene is that it reproduces its like at each nuclear division. . . Since a mutated gene is reproduced in its altered form it follows that one gene is reproduced from another. This is an exceptional situation. [This point was originally stressed by Muller(24) in I922. M.R.P.] A molecule of haemoglobin in a cell is not derived from another similar molecule. If it were, slight changes in the molecule would be perpetuated, and extra-nuclear inheritance would be as common as it is actually rare. But one gene is derived from a like gene. As the gene is of the dimensions of a protein molecule and does not consist of a number of similar parts, we cannot regard its reproduction as a process of growth by accretion ending in division when a limiting size is reached.

It must, on the contrary, be a process of copying. The gene, considered as a molecule, must be spread out in a layer one Baustein deep. Otherwise it could not be copied. The most likely method of copying is by a process analogous to crystallization, a second similar layer of Baustein being laid down on the first.

But we could conceive of a process analogous to the copying of a gramophone record by the intermediation of a 'negative' perhaps related to the original as an antibody to an antigen. The process normally stops when one copy has been made, or at least the further copies are not attached to the chromosome.

The whole problem of synthesis is an almost virgin field in biochemistry. And it is absolutely fundamental. If genetics had done no more than pose the question in its sharpest form, it would still be a valuable stimulant to biochemical research. But it has done a great deal more than this. Whereas the classical biochemistry has largely been concerned in analysis of the stages of catabolic processes such as the breakdown of carbohydrates to lactic acid or alcohol and the digestion of proteins, the new brand of biochemistry which will, I believe, arise from genetics, will be concerned largely with the stages of synthesis of such molecules as chlorophyll and cyanin [i.e. macromolecules, such as proteins. M. R. P.] And its final goal will be the explanation and control of the synthesis of genes.

Thus the rise of molecular biology was predicted almost two decades before it began to make its real impact. It was a very remarkable piece of insight-though there was still no mention of nucleic acids.

So I reach the last phase of my historical sketch: the bare decade between Avery and Watson-Crick.

This was very far from a mopping-up period. It was of immense significance that the specificity of the transforming agent had been shown to reside in DNA and not in protein-though there was great reluctance by many, particularly chemists, to accept it.

Even in 1948 , and succeeding years, Hotchkiss (43) was still having to argue fiercely to support his exceedingly careful work eliminating the participation of trace amounts of protein in the transformation phenomenon. However, with Hershey \& Chase's (44) demonstration in 1952 that bacteriophage left all (that is, experimentally, more than $99 \%$ ) of their protein coat and other superficial 'apparatus' behind on infection of the cell, it became very difficult still to maintain that nucleic acid was not the key substance in the maintenance of genetic continuity.

In the period immediately after the Second World War it was still fashionable and perfectly respectable, despite Avery's work, to consider proteins as the key self- 
replicating molecules, while in 1946 a chemist(45) could still argue that the specificity of the transforming principle might lie in the polysaccharide molecule of the capsule itself, acting as a specific primer (on analogy with the 'directing' action of dextran in biosynthesis of more dextran from sucrose) for further production, by a non-specific enzyme, of the same type of polysaccharide.

It took another 15 years or so for most workers to realize that DNA was not just another type of specificity but the origin, the fount, of all or most specificities: that all heteropolymeric proteins derive their information from DNA and RNA and not vice versa. Even Avery himself(4) leant over backwards to emphasize that showing the role of DNA in pneumococcal transformation did not mean it was the key heredity substance for all living systems! The attitude of most biologists at that very time could be typified by Dubos(46), who, in 1945, giving a full and fair account of Avery's discovery published only a few months previously, wrote: 'Definition of their nature (referring to competence factors) will eventually elucidate the mechanism of the transformation and will, one may hope, provide a pattern for the analysis of the phenomena of bacterial variability.' This was a restrained but perfectly reasonable comment which, however, completely avoided any temptation (if, indeed, any temptation existed) to extrapolate the phenomenon of pneumococcal transformation to the mechanism of heredity in general. Transforming DNA might explain some of those curious variations that were continually cropping up in bacterial cultures; that is all.

There were, indeed, a number of misleading clues and confusing facts which delayed progress.

Peter Walker (47) pointed out two of the most important of those red herrings. The first were the ideas of the I940s stemming mainly from some leading geneticists (48) indicating that nuclear DNA was broken down to nucleotides and resynthesized, possibly through RNA, during each cell division cycle. Despite many other facts supporting Caspersson's theories on the vital role of nucleic acids in cell heredity, these

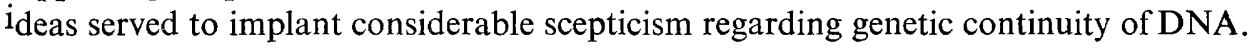

The doubts were supported by the second of the red herrings which arose from the apparent decrease in the ultraviolet absorption of the nucleus during telophase-an observation which was in fact due to a big relative increase of the u.v. absorption in the cytoplasm, from the synthesis of RNA, only later properly established by Brachet(49), and accumulation of nucleotides therein, and did not represent any absolute loss of nucleic acid from the nucleus.

However, during those days, other workers, in particular Chargaff and his colleagues in New York, and Randall and his group (including, of course, Maurice Wilkins and Rosalind Franklin) at King's College, London, had become interested in nucleic acids (from a chemical and physical standpoint respectively) as large molecules having an important biological activity. Their objectives were to try to discover, with the greatly improved techniques then rapidly becoming available, the basis of the specificity that must surely be present in the molecule. Unquestionably, one of the possibilities envisaged was the sequence of nucleotides in the molecule.

But Chargaff(50) was well aware of the difficulties, pointing out that identity of natural polymers is necessarily difficult because in many cases they will be 'substances that differ from each other in the sequence, not in the proportion, of their constituents'.

Up to this time- the late 1940 - the only DNAs properly analysed for base composition were those from higher organisms where the $\mathrm{G}+\mathrm{C}$ proportion of total base 
present in the DNA in different species is now known to range no more than from 40 to $45 \%$, in contrast with that in viruses and bacteria, which spreads from 25 to $75 \%(51)$.

Since the ratios $\mathrm{A} / \mathrm{T}$ and $\mathrm{G} / \mathrm{C}$ must be unity in double-stranded DNA (and that means practically all DNA), in DNAs where the $G+C$ proportion of the total 'happened', so to speak, to be nearly $50 \%$, it follows that the proportions of all bases must be approximately equal, and that, therefore, no variations between DNAs from what were then, of course, considered to be widely differing sources, could possibly emerge. One of the vital clues which led Watson \& Crick to the correct solution of the structure of the DNA double helix(1) was therefore lacking until Chargaff and his colleagues(52) started to analyse the DNA of yeast and tubercle bacilli in 1948/9. The $\mathrm{G}+\mathrm{C}$ content of DNA from these two micro-organisms are $36 \%$ and from 62 to $70 \%$ respectively of the total. This big difference thus highlighted the constant ratios of near-unity found for $\mathrm{A} / \mathrm{T}$ of 0.95 and for $\mathrm{G} / \mathrm{C}$ of $\mathrm{I} \cdot \mathrm{O}$.

Chargaff, though quick to spot a possible clue, was understandably reluctant to push it too far and simply commented as follows at the end of his 1949 paper(52): 'A comparison of the molar proportions reveals certain striking, but perhaps meaningless, regularities.' Further work(53) on DNA of Serratia marcescens, Bacillus schatz and Haemophilus influenzae showed analogous species differences and the same (approximate) relationship of $A$ to $T$ and $\mathrm{G}$ to $\mathrm{C}$, despite big, overall differences in $\mathrm{G}+\mathrm{C} \%$.

But an explanation had not been offered when two years later in 195I Chargaff(54) wrote: 'As the number of examples of such regularity increases, the question will become pertinent whether it is merely accidental or whether it is an expression of certain structural principles that are shared by many deoxypentose nucleic acids, despite far-reaching differences in their composition and the absence of a recognizable periodicity in their nucleotide sequence.'

Others were also working on DNA base compositions, no doubt with the same idea in mind, but they never got so far.

Mirsky's group (55) compared the pneumococcal transforming DNA with thymus DNA and found a rather lower $\mathrm{G}+\mathrm{C} \%$ in the former. Although the $\mathrm{A} / \mathrm{T}$ and $\mathrm{G} / \mathrm{C}$ ratios approached unity in both cases, no comment was made on their possible significance. The vital point may here have been obscured by the large number of other base compositions they analysed at the same time, mainly from animals, where approximately equi-molar proportions of the four bases would, of course, have been expected.

Wyatt(56) analysed the DNA of certain insect viruses and found $\mathrm{G}+\mathrm{C} \%$ values varying at least twofold with $A / T$ and $G / C$ ratios all around unity but came to the rather surprising conclusion that 'no direct parallel can exist... between biological relationship and DNA composition, since the groups having equal $A+T / G+C$ ratios include viruses as unlike as any examined'. This argument is difficult to understand if he had conceived that a most likely, or even a possible, basis of DNA specificity was in the nucleotide sequence rather than overall base composition. But, of course, it is easy to forget that at that time there could have been no theories about the nature of the DNA/protein code and that most people, in spite of Chargaff's warning, were probably thinking in terms of gross differences both in composition and sequence.

It might be, and often has been, asked why Chargaff did not pursue his findings more boldly. But in fact there were not then sufficient data available to go much further. No satisfactory techniques were available for sequencing nucleotides, and it needed a 
synthesis with the equally significant findings of Wilkins and Rosalind Franklin for the true solution to emerge.

The base ratio part of the story contains, nevertheless, more than its fair share of the irony in scientific discovery. No one yet knows why, so to speak, the DNA of all higher organisms has a $\mathrm{G}+\mathrm{C}$ content so close to $50 \%$ of the total bases as to have obscured a vital clue for so long and to have been at least partly responsible for persistence of the balanced tetranucleotide hypothesis which long delayed progress in the chemistry of DNA. There is no known molecular reason why this should be so, since bacteria and viruses seem to get on very well with percentages of $G+C$ ranging between 20 and 75 . Such a spread is quite consistent with what is known of the degeneracy of the nucleotide/amino acid code. It is, however, difficult to believe that the use of the code, which appears to be universal, and other factors which may contribute to the determination of overall base composition, have no biological significance. At all events a major piece of ill fortune seems here to have been involved.

On the other hand, it is very lucky that Chargaff did not begin his bacterial work with Escherichia coli (as most modern molecular biologists would assuredly have done!). This species has a $\mathrm{G}+\mathrm{C}$ content ( 50 to $52 \%$ ) not differing strikingly from that of animals and plants and such an analysis, at that particular time, would perhaps have so disappointed him and his colleagues that they might have concluded that there was nothing to be found out in DNA by that approach and given it up. An important clue might thus have been missed for even longer.

This short historical essay is, of course, a lamentably over-simplified account of a fascinating and all-important advance in knowledge. But the story is not, I believe, atypical of the sorts of factors that operate for many scientific discoveries. The eccentricity of human personalities, their prejudices, their personal ambitions, their unreason, combine it would seem with the vagaries of fortune to exert more influence on the detailed short-term course of events than the cold force of logic.

Above all, it shows how extraordinarily difficult it is for people to accept new ideas and thus how reluctant they are to try to do so-even though the ideas are simple, clarifying and basically quite easy to understand if approached directly, from scratch, so to speak, as a child would do. What a prison we seem to make of our own minds!

A striking instance of the slow permeation of a new concept is illustrated by the inclusion, in a textbook published as recently as 1960(57), of a diagram showing Haurowitz's 1949 (then not unreasonable) hypothesis(58) on the mechanism of protein self-replication by a direct copying process with itself as the template: an inclusion not introduced as an historical curiosity but as an indication of the type of mechanism which must be accepted as a serious contemporary possibility-with very little emphasis on the Watson-Crick hypothesis for the mechanism of DNA replication and all the evidence in support of it, as the fundamental process of biological replication.

'Great discoveries', as André Lwoff puts it(59), 'are dangerous.' They are often hated because they require the immense emotional (and therefore intellectual) effort of abandoning preconceived dogmata. And, because they are hated and feared, they are, as Goethe himself pointed out, nearly always subjected to ridicule. In the present story one particular instance, cited by Hotchkiss(31), occurred as late as 1954 at a symposium on transformation in the United States where an eminent bacteriologist asked 
sardonically, but in all seriousness, whether the genetic activity of DNA was 'based on evidence or was merely a voting agreement'.

Even now there are still a few sceptics in the sense of those who suspect that perhaps some (possibly biologically irrelevant) information can be supplied by proteins to DNA and other polynucleotides-as they are being formed. I suspect they may even be right. But very few would now say that such instances are common or very significant, although some well-known voices (60) are still heard as recently as I968 with vitalistic and almost meaningless remarks such as:

Biologists have confronted successively-like a nest of Chinese boxes-levels of complexity ranging from the eco-system to the internal chemistry of the cells. The last box has been opened. According to the Watson-Crick theory, it should have contained the single source of all the inherited specificity of the living organisms-DNA. It is my view that the last box is empty and that the inherited specificity of life is derived from nothing less than life itself.

There are, however, other sceptics of quite a different and much more interesting and valuable type who try to look into the future and consider how our present ideas may develop: those few who feel, like Pirie (himself one of the earliest workers to be concerned in the biology of nucleic acids), that the mechanism of information replication may not be so exclusively centred on nucleic acids as is fashionably supposed at the moment.

We may still be being misled by thinking we know more then we do-in a manner analogous, as Pirie(61) puts it, to the card-player who 'assumes that, although there are 52 types of card, only he knows which ones are in his hand because there is only one type of back to a card. He will fare badly when confronted with a card-sharper who has marked the backs so that there are 52 types of back as well. We may be victims of a similar subtlety when we discuss "information" transfer... for we have no means of knowing that we know all the clues that exist. Accumulated biological experience suggests that Nature is as subtle as any card-sharper.'

As a purely fanciful example, suppose we postulate the existence of some highly specific, hitherto unrecognized, slim macromolecule that is in fact necessary for proper replication of DNA (it could even be a type of natural DNA-replicating enzyme). And we suppose that this substance undergoes an extremely slow sequence of chemical changes that result in the 'inaccurate' replication of DNA of a nature such as to lead to a sequential series of modifications in the resultant proteins of a type that is biologically significant to the species concerned-a substance, that is, having the property of a directing entity responsible for non-Darwinian evolution. Well, such a hypothesis would, quite reasonably, be rejected with impatience because not only is there no evidence that an entity exists with such properties but (much more important) there is no real need for it at the moment.

Some time later on, when molecular biology becomes more complicated again, we can be pretty sure that analogous 'needs' will arise (probably in a very different context) and some major reorientation will again be required of us. Just because it is practically impossible to guess what this will be should not absolve us from realizing that it must certainly occur. It should serve to keep our minds as clear as possible from too monolithic and rigid assumptions.

In conclusion, it emerges that in the discovery of DNA there could be few more contrasting pairs of personalities than, on the one hand, Watson and Crick, who were 
prepared to stick their necks out and go well beyond the facts in a brilliant thrust of insight, and, on the other hand, Avery and Griffith, who were, if anything, unreasonably careful and almost too modest in their conclusions.

Both types of personality have their drawbacks and virtues, but in this instance what seems to have been of really crucial importance was that they followed each other in the right order: a matter of natural selection, of course, but still worth remembering as an occurrence of critical significance.

Since more is heard of glamour stories and flamboyant personalities in the advance of scientific knowledge than of the quiet workers and those long, tedious and superficially unexciting experiments, with careful controls, that may be just as important, it is well that we should also pay tribute to those who can do great work without noise. And I can do no better than to conclude by quoting Rollin Hotchkiss's tribute (34) to Avery: 'When men and ideas rub against each other, the ideas receive maximal polish if the man is gentle and his principles hard', because I think that applies equally to Fred Griffith.

I am most grateful to Professor E. Chargaff, Mr N. W. Pirie, Professor P. M. B. Walker and Professor M. F. H. Wilkins, who responded generously to my request for information of a personal nature relevant to the more scientific part of this lecture.

I am also much indebted to former colleagues and friends of Fred Griffith who, by providing first-hand glimpses of his life from their own recollections, enabled me to give some sort of picture of his personality as a background to this story. These include Dr V. D. Allison, Dr S. D. Elliott, Sir Graham Wilson, Mr W. R. Maxted and (very particularly) his sister-in-law, Mrs Stanley Griffith, whose vigorous and vivid reminiscences of 30 years or more ago were invaluable and themselves unforgettable.

\section{REFERENCES}

(I) Watson, J. D. (1968). The Double Helix. London: Weidenfeld \& Nicolson.

(2) Chargaff, E. (1970). Personal communication.

(3) Griffirh, F. (1928). The significance of pneumococcal types. Journal of Hygiene, Cambridge 27, II3.

(4) Avery, O. T., MacLeod, C. M. \& McCarTy, M. (1944). Studies on the chemical nature of the substance inducing transformation of pneumococcal types. I. Induction of transformation by a desoxyribonucleic acid fraction isolated from pneumococcus type III. Journal of Experimental Medicine 79, I37.

(5) Watson, J. D. \& CRICK, F. H. C. (I953). Genetic implications of the structure of desoxyribonucleic acid. Nature, London 171, 964.

(6) WiLkins, M. F. H. (1970). Personal communication.

(7) Kunn, T. S. (1962). The Structure of Scientific Revolutions. Chicago: University of Chicago Press.

(8) Medawar, P. B. (1968). Lucky Jim. New York Review, March 28, p. 3.

(9) WhiteHEAD, A. N., quoted by T. S. Kuhn (Ref. 7), without bibliographical reference.

(I0) Aluson, V. D. (1970). Personal communication.

(II) Mirsky, A. E. (I968). The discovery of DNA. Scientific American, June, p. 78.

(12) Olby, R. \& PosNer, E. (1967). An early reference to genetic coding. Nature, London 215, 556.

(13) Wilson, E. B. (1896). The Cell in Development and Heredity. New York: Macmillan.

(14) WiLson, E. B. (1895). An Atlas of the Fertilization and Karyokinesis of the Ovum. New York: Macmillan.

(15) WiLson, E. B. (1900). The Cell in Development and Heredity, 2nd edn. New York: Macmillan.

(16) Wilson, E. B. (1925). The Cell in Development and Heredity, 3rd edn. New York: Macmillan. 
(17) LeVene, P. A. \& Bass, L. W. (193I). Nucleic Acids (American Chemical Society Monograph Series). New York: Chemical Catalog Company Incorporated.

(I8) Hill, L. R. (1966). An index to deoxyribonucleic acid base compositions of bacterial species. Journal of General Microbiology 44, 419.

(19) Jones, W. (19I4). Nucleic Acids. Monographs on Biochemistry. Edited by R. H. A. Plimmer and F. G. Hopkins. London: Longmans.

(20) Hopkins, F. G. (1936). The influence of chemical thought on biology. Lecture at Harvard tercentenary conference on Arts and Sciences. Science, New York 84, 258.

(21) HopkINs, F. G. (1938). Biological thought and chemical thought. A plea for unification. Linacre Lecture, published in Hopkins and Biochemistry, 186 I-1947. Edited by J. Needham and E. Baldwin. Cambridge: W. Heffer and Sons.

(22) Elliott, S. D. (1970). Personal communication.

(23) Wilson, G. S. (1970). Personal communication.

(24) Muller, H. J. (1922). Variation due to change in the individual gene. American Naturalist 56, 32.

(25) Neufeld, F. \& Levinthal, W. (I928). Beiträge zur Variabilität der Pneumokokken. Zeitschrift für Immunitätsforschung 55, 324.

(26) Maxted, W. R. (1970). Personal communication.

(27) Dawson, M. H. ( I930). The transformation of pneumococcal types. II. The interconvertibility of type-specific S pneumococci. Journal of Experimental Medicine 5I, 123.

(28) Dawson, M. H. \& SiA, R. H. P. (I93I). In vitro transformation of pneumococcal types. I. A technique for inducing transformation of pneumococcal types in vitro. II. Nature of the factor responsible for the transformation of pneumococcus types. Journal of Experimental Medicine 54, $68 \mathrm{r}, 70 \mathrm{r}$.

(29) Alloway, J. L. (1932). The transformation in vitro of $\mathrm{R}$ pneumococcus into $\mathrm{S}$ forms of different specific types by the use of filtered pneumococcus extracts. Journal of Experimental Medicine 55, 9I.

(30) Alloway, J. L. (1933). Further observations on the use of pneumococcus extracts in effecting transformation of type in vitro. Journal of Experimental Medicine 57, 265.

(3I) HотснKIss, R. D. (I966). Genes, transforming principle and DNA. In Phage and the Origins of Molecular Biology, p. I 8o. Edited by J. Cairns, G. Stent and J. D. Watson. Cold Spring Harbor Laboratory of Quantitative Biology.

(32) BerRY, G. P. \& Dedrick, H. M. (1936). A method for changing the virus of rabbit fibroma (Shope) into that of infectious myxomatosis (Sanarelli). Journal of Bacteriology 31, 50.

(33) Fenner, F. (1968). The Biology of Animal Viruses, vol. I, p. 363 ff. New York: Academic Press.

(34) Hotchkiss, R. D. (1965). O. T. Avery. Genetics, Princeton 5I, I.

(35) PirIE, N. W. (1970). Personal communication.

(36) Avery, O.T. (1932/3). The role of specific carbohydrates in pneumococcus infection and immunity. Annals of Internal Medicine 6, I.

Avery, O. T. \& Goebel, W. F. (I933). Chemo-immunological studies on the soluble specific substance of pneumococcus. I. The isolation and properties of the acetyl-polysaccharide of pneumococcus type I. Journal of Experimental Medicine 58, $73 \mathrm{I}$.

(37) MiRsky, A. E. (1943) Chromosomes and Nucleoproteins. Advances in Enzymology 3, I.

(38) CASPERSSON, T. (1940). Methods for the determination of the absorption spectra of cell structures. Journal of the Royal Microscopical Society 6o, 8.

CASPERsson, T. (1947). The relations between nucleic acid and protein synthesis. Symposia of the Society for Experimental Biology 1, 127.

Schultz, J. (194I). The evidence of the nucleoprotein nature of the gene. Cold Spring Harbor Symposia on Quantitative Biology 9, 55.

(39) Gulland, J. M. (1947). Structures of nucleic acids. Symposia of the Society for Experimental Biology $\mathbf{x}, \mathrm{r}$.

(40) Darlington, C. D. (1942). Chromosome chemistry and gene action. Nature, London 149, 66.

(4I) Astbury, W. T. (194I). Protein and virus studies in relation to the problem of the gene. Proceedings of the 7th International Genetics Congress, 1939, p. 49. Cambridge University Press. AstBURy, W. T. (1947). X-ray studies of nucleic acids. Symposia of the Society for Experimental Biology I, 66. 
(42) Haldane, J. B. S. (1937). The biochemistry of the individual. In Perspectives in Biochemistry, p. I. Edited by J. Needham and D. E. Green. Cambridge University Press.

(43) Нотснкiss, R. D. (1949). Études chimiques sur le facteur transformant du pneumocoque. Colloques Internationaux du Centre National de la Recherche Scientifique (Paris) 8, 57.

(44) Hershey, A. D. \& Chase, M. (1952). Independent functions of viral protein and nucleic acid in growth of bacteriophage. Journal of General Physiology 36, 39.

(45) StaceY, M. (1947). Bacterial nucleic acids and nucleoproteins. Symposia of the Society for Experimental Biology $\mathbf{1}, 86$.

(46) Dubos, R. (1945). The Bacterial Cell,p. I87. Cambridge, Mass., U.S.A: Harvard University Press.

(47) Walker, P. M. B. (I970). Personal communication.

(48) Darlington, C. D. \& Mather, K. (1947). Elements of Genetics, chap. 7. London: Allen and Unwin.

(49) BRACHET, J. (I940). La détection histochimique des acides pentose-nucléiques. Comptes rendues de la Société de Biologie $\mathbf{1 3 3}, 88$.

BRACHET, J. (I947). Nucleic acids in the cell and the embryo. Symposia of the Society for Experimental Biology r, 207.

(50) Chargaff, E. (1950). Chemical specificity of nucleic acids and mechanism of their enzymatic degradation. Experientia 6, $20 \mathrm{I}$.

(5I) SUEOKA, N. (1964). Compositional variation and heterogeneity of nucleic acids and protein in bacteria. In The Bacteria, vol. 5, chap. 9. Edited by I. C. Gunsalus and R. Y. Stanier. New York and London: Academic Press.

(52) Vischer, E., Zamenhof, S. \& Chargaff, E. (I949). Microbial nucleic acids: the desoxypentose nucleic acids of avian tubercle bacilli and yeast. Journal of Biological Chemistry 177, 429.

(53) Zamenhof, S., Brewerman, G. \& Chargaff, E. (r952). On the desoxypentose nucleic acids from several micro-organisms. Biochimica et Biophysica Acta 9, 402.

(54) Chargaff, E., Lipshitz, R., Green, C, \& Hodes, M. E. (I95I). The composition of desoxyribonucleic acid of salmon sperm. Journal of Biological Chemistry 192, 223.

(55) Daly, M. M., Alfrey, V. G. \& Mirsky, A. E. (1950). Purine and pyrimidine contents of some desoxypentose nucleic acids. Journal of General Physiology 33, 497.

(56) Wyatт, G. R. ( 1952). The nucleic acids of some insect viruses. Journal of General Physiology 36, $20 \mathrm{I}$.

(57) PICKEN, L. (1960). The Organization of Cells and Other Organisms, p. I7. Oxford: Clarendon Press.

(58) Haurowitz, F. (1949). Biological problems and immunochemistry. Quarterly Review of Biology 24, 93.

(59) LwOFF, A. (1955). Control and interrelations of metabolic and viral diseases of bacteria. Harvey Lectures, series L (1954-55), p. 92. New York: Academic Press.

(60) Commoner, B. (1968). Failure of the Watson-Crick theory as a chemical explanation of inheritance. Nature, London 220, 334.

(6I) PIRIE, N. W. (1966). Biological organization of viruses. In Ciba Foundation Symposium on Principles of Biomolecular Organizations, p. 136. Edited by G. E. W. Wolstenholme and M. O'Connor. London: J. and A. Churchill. 